\title{
Robberies and Some Features of the Methodology of Investigating Robberies
}

\author{
Duraković Adnan \\ $\mathrm{PhD}$, Associate Professor, University of Zenica \\ Law Faculty, Bosnia and Herzegovina
}

\begin{abstract}
Robberies are crimes that particularly negatively and significantly affect the subjective sense of security (but also objective) in society. Special significance of robberies is that they are often on the edge of murder or serious bodily injury. From the criminal law and criminal investigation point of view, robberies range from the so-called "simple" cases in terms of their discovery and clarification to the very serious armed raid on individuals, money transport, legal persons such as banks and other monetary institutions. The suppression of property crimes, especially the part which includes delicts that are carried out using coercion (force and / or threat) like robberies, can be successfully carried out by methods that could be called criminalistic methods. These methods represent a kind of criminalistic engineering - criminal investigation engineering. Criminalistic engineering is all about adjusting criminal investigation tactics, forensic and legal actions and measures to special features of criminal offenses. When carrying out criminal investigation, authorized police officers must constantly take care of the so-called operational criminalistic strategy that rises above the tactical processing of a particular criminal offense, and is aimed at the creation and implementation of a complex of operational-tactical and technical measures and actions with the strategic goal of combating criminality as a whole. This is reflected in the organizational structure of the police and also in the way of criminal control which implies permanent, continuous and systematic penetration and supervision of the so-called the "dark belt" of crime.
\end{abstract}

Keywords: Robbery, Criminalistic Methodology, Criminalistics Control, Criminal Investigation

\section{Introduction}

Everyday robberies are made of large array of robberies on the street with the burglary of bags and the like, abounding in stores and shops, outlets, playgrounds, casinos, attacks on banks and other legal entities, money changers, gold jewelery stores, jewels, etc. . to robbing flats with or without previously established relations between the bandit and the victim.

It has been established that preventive measures after a certain period of time lead to changes in terms of possible perpetrators or modus operandi of known perpetrators.

The role of victims becomes more and more important every day. Citizens feel insecure because of the robberies and the style of life begins to change in some parts of towns or areas, until eviction. Mass media can play a negative role and spread fear. That is why people move to other distant and safer places.

Hacking bags and looting of drunk people, drug addicts, elderly people, children, disabled people, etc. belongs to the field of mass or occasional crime. There is a discrepancy between the priorities set by the police and those put up by the citizens. Police want to prevent attacks on banks and other monetary institutions while citizens seek protection on the streets and in their houses.

It was noticed that the police changed the police apparatus and organizational structure, management, treatment and regulations, but without significant shifts for the better. It is considered that it is more important to deal with issues related to the planning and conduct of criminal control and processing, criminal investigation and that is important to develop ways of acting that offer practical solutions for the relevant areas of crime. 


\section{Main part of work}

\subsection{Prevention and strategies}

Successful suppression of robbery depends of the knowledge of the criminological factors that enable or favor the execution of these delicts, as well as the knowledge of the so-called. geography of the robbery and strategy of the activities of the prosecution authority (repression). There seems to existbe an impression that the police is not sufficiently informed on this matter. The experience of police shows that it is important to develop specific ways of acting (strategies) that offer practical solutions in the area of robbery. General and special criminal control and police investigation played a great role in this matter.

Under criminal control in this work we mean: permanent, continuous and systematic penetration and supervision of the socalled criminal networks or potential criminal environments or individuals who are already known criminals or potential criminals. It is a system of all operational, tactical and technical measures and police actions directed towards gaining information about delinquency and delinquents, socially dangerous phenomena, causes and consequences of these states and phenomena, criminogenic and victimogenic factors and environments, etc. In other words, this is a form of police activity that is focused on criminality as a mass phenomenon.

During criminal control as a form of monitoring and studying crime and other socially dangerous situations and occurrences in a particular area (territorial principle), the police is moving to the middle of the "dark area" of criminality, undisclosed and unrecorded criminal offenses and perpetrators that is to the unpunished crimes. Criminal control primarily includes operational measures and police actions that are carried out in order to collect relevant information from various material and personal sources. Most often it involves the first information-orientation indications, which are often very scarce.

Gounds for suspicion are based on general indications and criminal experience of particular environments, places and faces. Criminal control in an organizational sense is not a particular form of organization but it is only a form of action. There are two forms of criminal control: 1. general criminal control and 2. special, line criminal control. This division is indicative and the boundary between them is not severely withdrawn, although the first is primarily implemented through the Basic Police -uniformed police, and the other through the Criminal Police Departments.

Criminal investigation is conducted in the occasion of a specific criminal event or criminal offense when the grounds for suspicion are higher. Crime processing is primarily carried out by the criminal police.

Law enforcement forces make a distinction between direct and indirect criminal investigation. Direct criminal investigation is a criminal investigation in which the police work is focused on specific criminal cases. Indirect criminal investigation is a criminal investigation that is conducted within a direct criminal investigation in connection with another criminal incident or crime. In accordance with legal solutions, the police must begin with criminal investigation (investigation) when there are grounds for suspicion.

The primary tools for the prevention of robbery should be sought in two police-strategic areas: the patrol service and criminal police department. It should be noted that the responsibility for solving the problem of robberies lies not only on the police, although it is their primary task since the police shares the responsibility for combating robberies with other prosecution authorities and the public in general. Certainly, an adequate criminal policy plays an important role.

Today, in the fight against robbery, the role of informers and police officers involved in the criminal environment as well as so-called flying squads in big cities is increasing. Effective suppression of bandits requires a differentiated set of measures and actions by the police, other prosecutors, citizens and potential victims in a particular social milieu. Today, a very wide area in the field of suppression of robberies is offered in the field of changing architectural and economic circumstances, implementation of construction and technical measures from potential objects of attack, in order to deter many profesional perpetrators or to completely exclude the occasional ones.

Observed world and country-specific trends give reason to believe and to expect that robberies of flats, shops, various outlets, etc., as well as individuals will increase. This is, among other things, conected with the successful protection of monetary and similar institutions. Also there will be a qualitative change in the way the robberies are conducted, for example, with increased hostage taking, expanded use of sophisticated technical equipment, and more. 
Police holds the first line of combat against robbers, reduces the fear of general public and increases the sense of security among citizens. However, when public media is informing the public about crimes, the negative consequences of this notification should be taken into account (declaring modus operandi that leads to the phenomenon of imitation, identity hiding (eg disguising), influencing the executor's calculations in terms of risk and success, developing neutralizing techniques of potential executors. Also, public can estimate media reports as sign of growing level of violence which is above the level that public can accept as a form of social risk and behavior. An increased fear of robbery can lead to promotion of an irrational policy of suppressing crime related to robberies.

The police must never lose sight of the strong expression of citizens' fear of robbery. Although often irrational and statistically unregistered, this fear leads to a great public sense of insecurity and therefore fear acts as socially destabilizing factor.

In all activities of the police, whether it is a basic police or a criminal police, one must never lose sight of the fact that the discovery of perpetrators is only a means of achieving an objective, which must never become the goal itself. It is difficult to appreciate the successes or failures of the police, since they can be judged upon two different approaches to police work results - first is increased number of detecting and second reducing the number of cases.

When combating robbery, one phenomenon should also be taken into account. Very vigorous efforts by the police in one sphere affect the crime in other spheres or leads to the "transition" of the perpetrators to another area of property crime, or end up with a change of location.

It was noticed that the police is motorized but lacks mobility since it was found often to be too centralized, specialized, highly bureaucratized.

Professionally organized and planed forms of robbery, as well as many which are the result of the current opportunity require targeted police countermeasures. They have to hit the "hard core" of the perpetrator. By developing strategies of countermeasures, the preventive police activities would be improved. In doing so, the police can ensure public order and security only if it finds the routes to built contacts and consultations with public.

Robberies occur in a wide variety of manifestations and because of that they require broad spectre of social and police countermeasures. The victim and its surroundings, like by one rule, were caught up in the act of robbery. The fact that young people commit this crime (because they have the psycho-physical abilities necessary for the robberies and as a rule they are disintegrated, and in a socially unfavorable situation), and that robberies are carried out in densely populated neighborhoods, proves that the police can not alone permanently and effectively solve that problem. The self-protection mechanisms of potential victims need to be significantly expanded, and a variety of measures of rational social policy for the suppression of robberies should be applied.

Uniformed policemen, who are in the daily vicinity of citizens, if there are not too many police officers, give the citizens a sense of security. In mass robberies, the basic and decisive police activity is on the street. It should be taken into account that the increased presence of the police should not have a technocratic, bureaucratic and motorized form. On the other hand, when it comes to spectacular attacks, there is another concept. It should carefully plan the inclusion of concentrated forces of specialists and major investigative groups.

Police and the public can only jointly effectively suppress or control this crime area. Without joint action, information sharing and mutual trust, an increased fear of robbing in public can not be avoided. Assistance and care for victims of robbery and understanding of their situation must be in the forefront.

Regarding the suppression of robbery, 10 general police strategies in preventing crimes should be taken into account. These are: (1) a visible increase in the police presence on the ground, (2) the strengthening of secret activities, (3) observation, (4) inspections, (5) the use of lawful permissible coercion, (6) dispute resolution, (7) and (8) controlling and disseminating data from police information, (9) spreading strategies for combating crime and seeking and developing new strategies, and (10) making different conclusions.

Crime prevention activities by the police are generally realized through four forms of police action: (1) observation, (2) prevention, (3) repression, and (4) prosecution.

Robbery Classification: 
Today's criminals classify robberies into four categories, with various types of people arriving as perpetrators using different techniques for the execution of robbery. Most often, the robberies are classified into:

1. Robbery in open spaces, called street robberies,

2. Robberies of vehicle drivers,

\section{Commercial robberies and}

4. Residential banditry or robbery in residential buildings.

Today, for successful suppression of robberies, it is not enough to insist on police strategic areas, patrols, and investigative services. Much more successful areas of creative strategies that exist within police options should be taken into account.

Other services and social groups should be engaged. The responsibility for combating criminality lies not only within the police, although it is its primary task. The police must share responsibility in this regard with the public. It should be borne in mind that the centralized exchange of information is important in the prevention of robberies.

In order to successfully combat robberies, it is necessary to know the common characteristics of these acts. Thus, some of the common characteristics of robbery in Europe are: (1) a multitude of different manifestations, (2) robberies as delicts of violence have a major impact on the safety of citizens, (3) robbery is often performed by younger executives who are in socially unfavorable situations; 4) robberies are increasingly being committed by drug addicts in order to obtain funds for the procurement of drugs, but also by other addicts, for example, gamblers, (5) the robbery has become a typical large cities' delinquency; (6) effective suppression of robbery presupposes a differentiated multitude of police measures and measures of citizens - potential victims who are adjusted to given social milieu; (7) easier mass forms of robbery are most effectively prevented by decentralized tactics of prevention, which are close to citizens, (8) the number of bank robberies is significantly influenced by bank security measures (security guards, surveillance cameras, alarms, especially silent, etc.) and payroll points. An important role is played by the training of bank employees and the connection of the notification system with the relevant organizational units of the police.

It is known that the presence of police officers in a uniform visible to citizens gives a sense of security to the public. When it comes to mass robberies, the basic and decisive police activity is on the street.

When it comes to the so-called spectacular robberies police should carefully plan the engagement of concentrated forces, and take care of the involvement of specialists from different professional profiles and major investigative groups.

It was noticed that in the area of small and medium-sized robbery (which are relative terms) there are certain shortcomings. Particular attention in these areas should be given to the increased sensitivity of potential victims with the focus on increased need for self-protection.

Having all these facts that in mind, the first response of the police, primarily uniformed, to the place of robbery, depends on the circumstances of each particular case and the orders received from the police dispatcher on operational duty.

We emphasized that the first task of the basic police officers-uniformed police is to check the report and to indicate, if it is true or partially true, to determine the exact location of the execution site in a geographical sense. The following is a clue as to whether the robbery has been tried or completed, or whether it is still pending, what was the mode of enforced coercion, etc.

Police officers who are going to the scene must carefully observe the events on their way of approach to the robbery site, especially if they already have complete or partial personal description of the robber or a description of the vehicle.

The primary and secondary tactical targets of police officers should be distinguished on the place where the robbery was committed. Primary tactical goals are: achieving public safety with the protection of victims and witnesses of robbery, as well as other citizens who have found themselves in the field of the activities of the robbers and the police themselves, and putting the execution place under tactical control of the police. Secondary tactical targets of police officers are submeasures of first intervention in the form of preliminary detection and investigation at the scene, capture of perpetrators by direct persecution, finding seized movable things, etc. 
When conducting first intervention measures, police officers must always keep in mind the possibility that the perpetrator has been hiding either in or near the object of the attack and that he can surprise police officers. Therefore, in more complex and more dangerous cases, considering the manner of execution, it is recommended to use police dogs for detecting attackers, i.e. defense dogs. One should always bear in mind that perpetrators surprised by the quick arrival of the police could be ready for every possible criminal action.

It is always necessary to take into account the possibility that perpetrators have technical means to capture police communications by radio. Therefore, whenever possible, police should send encrypted messages according to an earlier agreement. Upon arrival at the venue, the exact position must not be revealed, except in cases where assistance is requested. Available patrols need to "cover" the area surrounding the scene. Police sirens, which allow a quick break through to the scene, should be shut off timely, while police alarms should be used at the discretion.

It has been observed that sirens can cause panic among the perpetrators and end with the use of violence or taking hostages. It is believed that most of the hostage-taking situations are caused by the overly visible and quick response of the police.

When approaching the place of events, police officers must avoid routine behavior, because every criminal case is a case for itself. In doing so, the police can use one of the following approaches:

a) Action-based template action, which is often the result of an incomplete factual situation at the place of events and acting upon previous experience,

b) Temporal treatment given the personal description of the perpetrator, when policemen expect robbers to look the way they do not really look, enabling robbers to escape or attacking police officers and

c) Situational template behavior, when cops previous experience in similar cases apply stereotypically to a new specific place of events and a situation on it.

For most police forces in the world, the rule which applies that all persons who leave the attacked facility, either on their own initiative or on the request of the police, is that they must be searched and identified if the robbers in the attacked facility can predict the possible way and direction of their escape. It is also necessary to anticipate the places where possible helpers can be found. If the assassins begin shooting at police officers, they should return to the fire, but without bringing into danger the lives of third parties, such as hostages, victims, casual passers-by, witnesses. It is better to allow the escape of a bandit than to kill an innocent person. On the other hand, when the escaping execute is not aggressive, but refuses to discard a firearm or other dangerous substance, in principle, the police can notuse fire unless it is estimated that the fugitive will attack. As a rule, a deadly force or a deadly shot should only be used as the ultima ratio.

When the perpetrators are barricaded or held hostage, as indicated above, specialists for negotiation and special police units should be called in with the simultaneous evacuation of the surrounding area, as previously discussed.

Initial research:

The scene of robbery contains numerous traces, especially micro and invisible (latent) traces and objects related to the robbery. They can only be found after a detailed examination of the scene of the crime and its surroundings during the investigation, and some traces only later in the experts' labs. That's why the police officers involved in the measures of first intervention must be aware of the rules for securing the scene of the crime with remains as much preserved as possible, or to change little as possible, or not to generate new traces or destroy or contaminate existing traces.

Insuring and reviewing the crime scene:

Since the testimonies of the victims and vitnesses, for a number of reasons - explained in detail in criminological psychology, are uncertain and changing category, the search for the so-called " material evidence in the form of traces and objects of a criminal offense", must be thorough and persistent.

The manner and scope of the search in the phase of the initial intervention are determined by the type of property, the place of the criminal event (open or closed), as well as objects and substances important for the case. Measures of the first intervention by the basic police characterize the informal, offensive and mass behavior. 
For those who provide securing a crime scene, special interest should be on the places where perpetrator was standing or sitting, squatting, lying, etc., the objects he contacted, found the resources of immobilisation of the person (means of binding, especially adhesive tape, because they can capture fingerprints if the perpetrator worked without gloves, etc.). These places and objects could be found and indicated by the objective situation or they can be found out on the basis of person's statements. Everything that has been found needs to be described and recorded.

Victims and witnesses should be separated and gathering information shoud be made by interview type talk. Interviewing should be done as soon as possible and must be detailed. At the same time, it is necessary to work and make parallel collection of information from other available sources of information. The basic principle of interviewing people is that people must be examined separately from each other. Interviewing victims and witnesses is done in the situation when their status is known with certainty. The focus is on the certain specificities and the circumstances of each particular case. It needs to be determined whether the victims and witnesses talked to each other before the arrival of the police, and if so what they talked about.

Based on the content of the testimony of the victims and the witnesses, the investigators can later link the parts of the criminal event and carry out a mental reconstruction of the event, chronologically using historical method.

It is necessary to try to identify the identity of the persons who were in the vicinity or in the object of the attack, just before the attack, and at the time of the attack. Among them can be the accomplices of the robbers. These persons may be known only by name or surname, nickname, alias, occupation, place of residence, place of detention, etc.

The focus should be on collecting information on the modes of execution of the crime, with particular emphasis on modus operandi. The following information is provided on the number of perpetrators, their personal description, the roles they had in the execution of the offense, the ways of communicating immediately before and during the attack, the manner of addressing the attendees, the manner and direction of the escape, the places and objects they contacted during the commission of the crime, etc.

Collecting data about the form of attack in terms of the applied force and / or threats and the stages of the execution of the work (ante delictum, tempore delicti, post delictum) is important for making the correct conclusions based on the analysis (assessment) of the state and the prognosis. An important role is played by the aforementioned thought process of constructivization. It is directly linked to operational and process activities. Based on the process of identification, differentiation, analysis and synthesis, deduction and induction, abstractions and approximate generalizations, the boundaries between the individual traces and objects are determined, as well as their properties, relations and coexistences, etc., in order to better operate with them.

In order to avoid omissions and oversights when taking the measures of the first police intervention, especially when ensuring the place of the event, the basic police officers should use a kind of operational reminder, especially when it comes to elements of personal description.

Special attention should be paid to the points and directions of the escape along with the timely blockade of the area of the event. Based on the testimonies of these persons and those from the scene, the images of the executor, the used vehicles, etc. can be "collated" later in the process.

As already mentioned, special attention should be paid to gathering information on words used by the perpetrator or perpetrators, which may constitute an identification mode of modus operandi. Data on the physical fitness of the perpetrator, his skills and abilities, including data indicating the use of alcohol or substances, possible disguise or methods of disguise, etc., should be collected. One should always bear in mind the possibility that one of the perpetrators visited the object of the attack before the attack under a certain excuse, in order to get acquainted with the layout of rooms, number and composition of the personnel, etc.

\section{Identification of the suspect}

There are different ways of identifying suspects that have been elaborated in detail in the framework of criminal intelligence. Identification is repeatedly disabled or made difficult by direct recognition by victims or witnesses, when the perpetrators were disguised (masked). Many robbers use different types of facial mask such as: ski masks, gas masks, special masks, women's socks over the head, scarves, evereything up to paper bags with eye openings. Another way of dressing involves 
wigs, hair painting, false impressions, beards and mustache, false noses, beards and ears, false scars, various forms of make-up, all in order to change the personal description.

The fact is that different tools and weapons for execution of robbery lead sometimes into the zone of attempted murder or borders with it. That objects can be found at the place of execution or may be discarded near the execution site during escape by foot or vehicles, may be hidden in vehicles and elsewhere. They can be a rich source of material information after processing in forensic laboratories. Therefore, they should be properly exempted and packaged in a proper manner not to cause destruction, damage or contamination in a traceological sense, or generate new traces that are not related to the performed crime and perpetrator. Razors, blades and medical scalpels, especially when they are larger in size, will be especially intimidating to the victims.

Most vehicles that bandits use in the phase of preparing execution of the offenses, as well as escape phase, as a rule, are inconspicuous in their appearance, so they "drown" in the environment. They are such that they do not attract attention in any way, look, sound, etc. As a rule they were stolen immediately before the robbery or short time before the robbery, in order to short time for detection the theft of the vehicle and informing the police about the theft, until the moment of the robbery. Fake or stolen registration plates are used also. Some robbers leave the place of execution on foot, and short time after that they use vehicles.

If vehicles for robberies have been found earlier, they are kept hidden in secret garages and similar places, as well as auto mechanic and lacquer workshops, and if they were stolen, the bandits then would make the necessary changes on them.

In cases when the perpetrators of the robbery are caught at the scene during the course of the robbery (in flagranti), modus operandi in a specific case must be compared with earlier cases, but also subsequent ones, if they occur. In this way it is possible to detect serial bandits.

Modus operandi in operative criminal record of special interest is defined by the following elements: (1) type of robbery (model), (2) execution time in terms of day, hour and minute, (3) manner of execution, (4) means of execution, (5) number of executors and their approximate age, gender, appearance and the like, (6) voice and vocabulary used, (7) used vehicles, (8) various special features, (9) searched and confiscated objects, etc.

Finding a modus operandi of earlier robberies that coincide with the manner of carrying out a particular robbery does not necessarily mean that the same bandit committed these robberies. It is noteworthy that some of the bandits, after having learned through the mass media about the manner of execution of a robbery, take over this mode of operation and imitate it, which can lead to delusions.

Material evidence, especially visible ones, is modest in the case of robberies in relation to some other crimes. If the objects of the attack are equipped with cameras, secret

or public surveillance or other technical registration means, technical recordings can serve as a good source of information and proof in technical terms.

All detected material traces and items related to the committed robbery can be used for detecting purposes. Finding certain types of traces depends of the location and methods of execution. So, for example, in cases of robbery with the physical contact with the victims, there are more material traces than in the so-called street robbery. In the case of the escape of the vehicle, the traces of the tire remain visible or invisible depending on the surface.

Particular details should be analyzed in cases of wounding a person in execution of crime during or immediately after the robbery. It is necessary to check the time of sending the first messages from the dispatcher to police units after the first information were sent from the crime scene, especially those concerning the personal description of the attacker and the description of the vehicle. It is also necessary to analyze whether the place of the event was properly secured, whether and how the objects, etc., were taken away, which objects were taken away by the robbers, who was the legal owner or possessor, etc.

If a perpetrator is deprived of liberty it is necessary to determine when and how it is done, how it is identified and whether its availability is made by the authorities and other persons according of the criminal procedural law. 
As pointed out, it is necessary to compare the cases of committed robberies, not only in the area of the police body concerned, but also in other bodies -teritorial princip. On the basis of monitoring the conducted robberies, potential objects of attack can be predicted and warned of this possibility.

\section{Methods of execution}

The criminal offense of robbery is characteristic because in most cases it is successfull. It is often a delicate crime with relatively little risk, except in the case of attacks on money institutions, in terms of the success of its outcome. This is attributed to the circumstances which follow this crime, because it is usually carried out suddenly and very violently, so that the victims fail to provide effective resistance.

A considerable number of robberies are carried out in complicity with a certain division of labor, with the increased social danger of these acts. However, in a significant number of cases accomplices usually do not act on the basis of pre-detailed plans, but on the basis of current joint decisions, which are often due to the circumstances.

In a large number of cases, perpetrators use their own physical strength during an attack. When it comes to group robbery, the apparent numerical, and therefore physical strength, makes the use of weapons or other means of execution unnecessary, except in rare cases. On the other hand, individual robbers tend to use weapons or tools as means of execution.

Alcohol has a dual role. Alcoholic bandits are easier motivated and faster to decide on the execution of the act. On the other hand, alcoholized potential victims are also a vulnerable (suitable) object of attack.

Regarding the manner of execution, robberies appear more rarely in an attempt. The role of helpers and supporters it is not that important. Usually these are co-perpetrators. As a rule, complicity occurs shortly before the execution of the act.

The range of the mode of execution varies from case to case, from very primitive ways, to very perfidious attacks on vehicles, when in the vehicles are installed devices that later can be stopped and attacked on the road at a certain place. The modes of execution not only vary from case to case, but are also different for individual bandits. The execution method generally includes:

1. Preparations for the execution of acts, which may be very small and short,

2. Plan of the manner of execution of the offense (attack), even if it is currently adopted.

3. The type and method of applying coercion in the form of force and / or threat,

4. Procedure with victims and witnesses,

5. Taking away items,

6. Number of participants in the robbery, their roles and tasks to be performed by some of them, for example, who will be the leader of the group, who will keep the victims "on the eye", who will search them, who will guard the security personel, and so on.

7. The mode of dispatch (transport) of seized items,

8. The method of cashing or breaking up the seized goods, etc.

Among some forms of robberies, there is hardly any similarity, for example, between the robbery of banks and the taking of bags on the streets of street robberies.

That is why is difficult to track robberies through the modus operandi system. The methods of execution are very diverse and are conditioned by the nature of the crime itself, by the place of execution, by the personality and by the number of robbers, as well as by the personality of the victims. As a rule, robbers seek money and more valuable things (jewelry and other valuables, technical goods, weapons, and all other types of goods). Sometimes the objects of interest are various secrets, research results, patents and documents. Bandits are ready to attack the disobedient victim very brutally. They very rarely show a message on paper and avoid using voice. 
The objects of attack vary from various legal entities and institutions such as banks and money institutions, post offices, exchange offices, gas stations, catering and tourist facilities, jewelers (jewelers), houses and flats and individuals.

Victims of robbery are always physical persons. These can be cashiers and other cash dispensers, posters, collectors, drunken persons, homosexuals, prostitutes, wealthy persons, persons who sold or raised money in the bank before the robbery, taxi drivers, etc. All citizens are potential victims of the robbery.

Serious robberies are organised by preparing the plan of the action. This indicates the professionalism of the bandits. In all robberies one should distinguish between the preparatory phase (which may be very short) and the implementation phase. Examining the terrain, traits and habits of the victims, studying the (dinamics) and behavior of the population in a particular area, selecting the most suitable time for execution, determining how to overcome obstacles, defining roles in the division of labor, the way of coming and leaving the place of execution, defining the way of concealment and the place of concealment, arranging an alibi , and arranging story to be told to the police in case of capture and etc. all this falls into the preparatory phase.

Robbers make reconnaissance in various ways, personally or through their accomplices who may be employed in a potential object of attack or some other object of interest. These can be home helpers (maids), waiters, prostitutes, macros, sellers, different kind of officers, etc.

Whenever the robber wants to cover up the presence indication at the place of execution before committing the offense, he uses the helpers. This extends the circle of persons involved in the case and in some way makes robber more vulnerable to detection. Reconnaissance methods are numerous. This can be a check of tenants listings in residential buildings (mailboxes or intercome titles), postman and cashier tracking, watching the guests in catering facilities, tracking persons at fairs and markets, studying the organization and working in legal entities as the future objects of attack, especially banks, etc.

The reconnaissance involves awareness of life habits of victim, perception about the area and the object of the attack (selecting the object of the attack) and the opportunities in the facility, identifying the most suitable moment and time of attack when the frequency and movement or visit of citizens is the smallest, selection of the period of the day for example the night or the twilight, etc.

On the basis of the reconnaissance results, the perpetrator or perpetrators chose the way of execution and determine the role of individuals, the method of masking (placing women's socks over the head, various facial masks (so-called phantom), ski hats with eyebrows, scarves, wigs, false mustaches and beards, all to the masks for "masked" bals). Disguise and masking also include changes in color, voice, gesture, body stamina, etc. It was noticed that the robbers were shot in places where they knew them, or where there are technical registrations, such as cameras.

The preparation phase is typically characteristic for gangster-style robberies, also called complex robberies. Each bandit has its own way (style) of conducting preparatory actions and its way of performing acts.

Planning, disassembling and the way the robbery is executed can serve as a guide to clarifying the robbery. The basic elements of the robbery plan are precautionary measures. Some bandits require very little planning in connection with their execution. Second, given the protective measures taken as protection against robberies, they require more precise planning, often long-term and precise determination of time and manner of execution. In order for the police to successfully discover and clarify the robberies and robbers, they must know what the robbery plans contain. Therefore, we are specifying some elements of the robbery plan.

Usually these are:

- Observation of the potential object of the attack and its surroundings,

- The study of the way of life (the regime of life) of individuals who will be the victims of the attack,

- Study of the work of police patrols and the attendant and the speed of their response in urgent cases, as well as other police procedures in the area where the potential object of attack is located,

- Determination of the most suitable and as accurate time for the attack, 
- Drawing of cards and sketches or the acquisition of maps and sketches of the area and the place and object of the attack, as well as the recording of those places and persons of interest,

- Organizing and determining roles of the participants in the work, with the necessary division of labor, as well as practicing these roles.

- Agreement for the purchase of a vehicle, determining the type, color and the like. and persons who will carry out illegal procurement,

- Determination of the waiting area of the escape vehicle and escape vehicles used to escape (hot-air vehicles) and passage into other (cold) vehicles,

- Determination of the driver and their acquaintance with the escape route and alternative (alternative) routes,

- Necessary equipment, weapons, masking and dressing devices, means for binding and immobilization of faces, alarm systems, etc., as well as the overcoming of members of the so-called " physical protection" (guards and protectors),

- Determining the means and means of false representation ie. false identifications (such as policemen, military personnel, postmen, inventors, etc.). Places and ways of gathering before the commission of the act, as well as after the execution, and the agreement and training of the factual story to be told in case of capture by the police,

- Study of traffic flows and traffic disorders in the area of attacks, especially for the last 24 hours, etc.

\section{Implementation phase:}

Under the implementation phase, the method of executing robbery should be understood. As pointed out earlier, there are numerous ways to commit robbery. Here are some of the methods for executing the robberies:

1. Attacks in the open space, at a convenient location decided by monitoring, seduction, waiting or interception of the victim at a convenient time. There may be obstacles on the road to stop the vehicle, etc. dark parks and streets appear as suitable places. The attack often implies choosing a victim in advance ("tipping the victim").

2. Attacks by serving tricks and phishing. The robbers are represented as an official person, usually a policeman, a military person, an inventor, an interviewer, and so on. Reconnaissance is conducted to select the victim and then follow sudden approaches to him or her at a convenient place and moment. The victim sometimes is legitimized, and even "deprived of liberty". The robber in disguise can conduct and perform personal search, and then suddenly attack, strike and throw the victim on the floor and take away the things and disappear. The cases were reported that the robbers came as policemen with a false order (and in uniform) to search the apartment and then attacked the people and robbed them. This is the socalled contact mode of execution. They are successful in achieving intent when presented as collectors and deliverers (distributors).

3. Various attacks on individuals outside the home. Often, these are attacks on drunk, drugged, etc. persons and women. These attacks, as a rule,are performed by individual robbers, who are not particularly daring and bold. They use the weakness of the victim and the circumstance that victim can not provide serious resistance, as well as the moment of surprise. As pointed out, the attack is often preceded by scouting and monitoring.

4. Luring victims. Men and women are used as baits, with the victim who was being taken to a pre-arranged place where the attack occurs. Usually, prostitutes and persons of homosexual orientation or gamblers, etc., are used. These are robberies of scam.

5. Attacks on casinos, night clubs, banks, money orders, etc. The frequent objects of the attack are illegal casinos. Attacks on banks are carried out in a group, often with the use of gross violence and injury and death of clients of the bank and its employees.

6. Attacks on trains, or postal wagons on an open railroad. These attacks are preceded by detailed planning of attacks.

7. Sudden attacks on persons in flats and houses. After the previously conducted surveys about the arrangement of premises in the apartment or house, accesses, exits, telephones, alarm systems and other methods of protection, about places where there are more valuable objects placed or hidden, about the number of people that live in the apartment, 
information about how many persons are in the apartment at the time of the attack, gender, age structure, occupation, whether they know some martial arts, whether they are armed, etc., and after that approaching folllows the attack. Robbers are watching homes and apartments using strong binoculars, listening the telephone conversations, asking neighbors under different pronouncements, and so on. They can have an accomplice in the house, for example parlormaid. Some postmen, collectors, plumbers, etc. can consciously or unconsciously, with a glass of alcohol in the pub, provide the robbers with the necessary information. In some cases, they sneak into a residential building and wait for the arrival of the householder, and when they break up and take off. At the moment of surprise, a man who is half naked or naked for psychological reasons clumsily defends, is blocked by shock and does not think about escaping. Some climb into residential rooms over balconies and roofs in various ways (ropes, hooks, creeps along the facade, etc.). The third knock on the door and immediately switch to attack. They are very brutal and, as a rule, they bind victims and shut their mouths. Those who appear as inventors, suppliers, etc. or use other tricks to attack suddenly, they may be unnecessarily rough to prevent possible resistance. These attacks often take place based on the current assessment. Sometimes the robbers leave victims naked and bound.

8. Special forms of robbery are attacks on taxi drivers and drivers of freight vehicles that transport money, goods, etc. These robberies have all the features of gangsterism and often end up with bodily injuries or killings of victims. When it comes to taxi drivers, some epidemics of attack on a taxi driver occur in some countries, often with a fatal outcome. Often, a freight vehicle is taken along with the goods.

9. Attacks on cashiers eg. at railway stations and bus stations, doctors, dentists, lawyers, all those who have money at home. Robbers usually wait as clients, patients, etc. until they come to order, and then go into attack.

10. A special way of committing robbery is performing the attacks in elevators, either by monitoring or by waiting for victims, which at some times end up with rape (irradiation of the affect).

11. Attacks on personal car drivers in parking lots, in front of garages, at traffic lights, and so on. Drivers are often victims of auto stopers. When it comes to robberies by drug addicts the consequences could be tragic. Often, the robbers take away a vehicle and after the escape they often ignite cars to destroy the traces.

12. Insolent gangster attack are performed attacks on guests and staff in catering facilities, on passengers in trains, buses and other means of transport.

13. Attacks on jewels, goldsmiths, exchange offices, post offices, gas stations, shops, retirement homes, etc.

14. Attacks on persons of homosexual orientation, prostitutes, gamblers, etc.

15. Throwing into the eyes pepper or variety of sprays, electro stunners and the like.

16. Form of robberies performed by getting to know the victim and getting closer to her on the dance, in the cinema, in the catering facility, in the beach, etc. with performance in a convenient place and sudden attack. This is the so-called "blitz" attack.

17. Attack on cashiers, posters, inventors and persons who transport or transfer money. Often someone is involved with a robber from a legal entity in which a money transferer works.

18. False promises and misconception eg. by showing the street or persons, by contact for sale or purchase, by promising sexual intercourse, by offering assistance, by organising meeting with a person, in order to arrange a deal (and also unlawful) by providing "help" and "services" by wearing things and luggage, promises of transportation, etc. There have been cases where "aid" has been provided to the blind persons who have been robbed.

19. Attacks on lonely love couples, which at some times due to irradiation of an affair can end with a rape (female or male).

20. Robbery committed in combination with another criminal offense eg. by rape, by committing blasphemous actions, deception, seizure of a motor vehicle, etc.

21. "Ad hoc" street robberies, when a robber breaks (sweeps) up the pedestrians from the hand or from the body, for example, bags. Often the perpetrator push the victim on the ground and strikes, or only in the passage pulled out of the hand or from the body bags or other objects. 
22. Ordered robberies. In them, the victims are attacked by order. These persons have various valuable items that are considered as cultural, numismatic, philatelic, and similar merchandise. These may also be documents that represent military, official, business and other secrets, patents, etc.

Though robbers do not always use the same methods (methods) of execution, the connection of their attacks with one type of victim or objects in which attacks are carried out, without occasion bandits (i.e. those who have used the shown opportunity to perform the work), there are always some noticeable similarities in terms of the type of victims or objects of attack. Therefore, comparing the method of execution in unresolved robberies with the data in various operational criminal records, especially the modus operandi records, it is possible to identify undisclosed perpetrators.

The type and classification of robbery is often an indicator of someone's particular interest in certain types of victims or objects of attack.

Regardless of the various variations in the execution of the robbery, according to the mode of execution, criminals are generally classified into the three "style of work" for the operational needs of the robbery:

1. robbery from ambush,

2. robbery by the raid and

3. robbery with pre-planned criminal operations.

Robbery from ambush is based on the moment of surprise and does not require specific planning. The lack of detailed planning does not mean that the perpetrator did not think about the manner of execution and that he did not created a model of attack and execution of the act in his head.

Robbery by raid is characterized by a minimum of irregular planning. The attacks were temporarily selected and reviewed very quickly and the possible approaches to the execution of the offenses were selected quickly. In such cases, several robberies can be carried out in a quick sequence (sequence). Then we are talking about a series of robberies and serial robber or robbers.

Robberies with pre-planned criminal operations were explained in previous section.

Checks in the neighborhood:

A significant number of robberies is successfully solved by policemen, within the framework of the first intervention measure, if they are doing their job well. In the first operational stages of the proceedings one has to search for: (1) the suspect and (2) the sources of evidence, therefore, evidence. This includes the collection of information on possible earlier robberies at or near the site, in particular if it is the same victim or object of attack, additional witnesses of earlier cases that were not caught at the scene, and so on.

After the offense is committed, the robbers try to avoid detection by frequently hiding in the vicinity of the execution site. That's why the checks in the neighborhood play a big role. These include interviewing persons resident in the area in order to obtain information as to whether they have noticed what could be brought about in connection with the conduct of the robbery.

The term "noticed" implies perception of all senses. Field search is one of the tasks of checking in the neighborhood. Residents may recall seeing someone who was suspicious to them on the day the robbery was committed, but also earlier days. They could hear or see someone running through the yard, climbing over their fence, someone crying, they could hear dog barking, and so on.

These checks may reveal that a person under operational supervision is staying in the neighborhood. Neighbors know the people who have dealt with the law enforcements representatives. These persons can serve as helpers, concealers, etc.

In addition to interviewing residents near the site of robbery, all possible hiding places should be carefully searched. Here also tenants can help. The suspect may be hiding in places such as: spaces below or inside a vehicle parked near the place of execution, garages, sheds, garbage containers, churches, tree canopy, and outer premises, entrances in restaurants, shops, barbershops, motels and hotels, in legal or illegal "beds", by stopping taxis, etc. 
Often, controling the vehicle registration numbers in parking lots near the site of robbery can reveal the vehicle of an executor who for some reason did not want or managed to escape. Likewise, controling of parking notices on the penalty for exceeding the parking time can lead to the identification of the perpetrator. Checking in the neighborhood can reveal that the robber took away and used someone else's vehicle for the escape, etc.

Neighborhood checks should also be used to search for all places where the means of execution, prey and precious objects could be found.

\section{Conclusion}

On the timely and adequate handling of operational police center, depends the success of the police operational activity of any type.

The operational police center takes over command and control of the police forces (primarily the basic police) in the first stages after the robbery was committed. It coordinates work among particular police units, especially between the unifomed and criminal police, and has the role in the coordination between the patrols. It can order blocking and setting ambushes, searches of open spaces, and is authorized to give orders to police officers and patrols. It is also involved in resolving the case by communication and exchange of knowledge and information about the robbery from the personal description of the perpetrator, the route and the manner of escape of the perpetrator, the description of the vehicles used for escape and other relevant information for the case.

In accordance with these activities, operational center determines the number of police officers needed for the case, their ranks and professional profiles, determines the place of first intervention, and also manages cases when a large number of police officers and technicians are to be sent to the scene.

Of the numerous measures that must be taken on or after the day of the robbery that are mentioned before, the following measures and actions need to be included:

- search for stolen or abandoned vehicles with an overview of the "hot" list of stolen cars and comparison with the description of cars seen near the site of robbery,

- inquiries and inspection of garages for rent, and inspection of parking lots and their nearest surroundings,

- engagement of informers and other so-called legal sources to obtain information about a possible perpetrator,

- checking taxi drivers whether they "picked up" customer at a critical time near the place of robbery,

- conducting interviews with drivers of public transport vehicles that passed near the crine scene around at the time of the robbery or immediately afterwards, what they noticed, which passengers were connected, whether they were suspicious, etc. It should be kept in mind that professional drivers of public transport vehicles over the years sharpen their possibilities of observing the unusual behaviour at passengers,

- checking hotels and motels, bus and train and other stations, airports, ports, bars, casinos etc. to the extent that it is necessary in the particular case.

- return to the scene at different times in the following days in order to possibly find additional witnesses or check whether the already known witnesses recalled something new, which could be of interest in clarifying the case,

- fenced space with "Stop police" tape, as a kind of psychological barrier, should be kept confined all the way until the circumstances of the concrete case require,

- all available technical recordings should be used during the process, etc.

The most common defense of the robbers is that they bought the item from an unknown person, found it in a place, replaced it for another object etc. Finding and analyzing traces of operational and expert "demolish" such defense. When searching for items seized, the rest should be taken into consideration of the packaging that could have remained, although the perpetrator removed the object. There can also be traces indicating the presence of the object. When the object of the attack was money, it should be placed under the control of places where legally and illegally money is spent, from the shops, casinos, betting shops, to the stores of expensive goods. 
All police authorities should dispose the pictures and data of the most important facilities in their area that are potential objects of robbery. Primarily these are objects in which you handle large amounts of money, jewelry and other valuables, valuable goods, and so on.

There should be a constantly elaborated plan of a quick police response in cases of reporting robbery.

Checking what physical and technical protection measures have been taken in these facilities is also important. If, in the police opinion, these measures are not satisfactory, their amendment should be initiated. Particularly important role is played by public or secret cameras for permanent or occasional supervision. It should be checked whether they are really turned on or installed only to deter the possible perpetrators.

A special role is played by the so- called "redemption stations" of criminals who purchase items obtained through criminal offenses at low prices.

In the detection of robberies and search for perpetrators, records of certain categories of perpetrators should also be used. In this record, the returnees, are presumed to be registered (which are supposed to repeat the act).

Special role in controlling robberies have concealers who provide assistance to perpetrators of crimes after the committed act. Usually it is done by concealing things. He is the economic backbone of the criminal. Some hikers are also landlords who systematically educate the robbers who are with them as sub-tenants. Criminals and relatives are interconnected. Concealers know which goods are being sought and often give "order".

When setting up a criminal differential diagnosis (the theory of crime), the question should be asked: is it necessary or possible to involve the concealers ? Cousins, friends, acquaintances, love partners of robbers should also be checked. The elimination method should close the circle of suspicious faces that come to a mind. When a circle of suspicious persons is determined, secret surveillance should be carried out. Robbers usually do not carry items instantly, but hide them in a hideout, pre-determined place, so the concealer's role comes later.

\section{References}

[1] Aleksić, Ž., Škulić, M. (2002) Kriminalistika, Dosije, Beograd.

[2] Aleksić, Ž., Milovanović, Z. (1994) Kriminalistika,Partenon, Beograd.

[3] Baniak, S. (1978): Suzbijanje razbojničkih napada i sprečavanje ovih zločina u velikim gradskim aglomeracijarna , "Izbor" br. 1-2, Zagreb.

[4] Barker, M. i dr. (1993) : The prevention of street robbery. London, Home Office.

[5] Basarić, M. i Vejzagić, N. (1998) Kriminalistika II. (kriminalistička tehnika), Fakultet kriminalističkih nauka, Sarajevo.

[6] Lakčević, D.: Kriminalistička kontrola i obrada razbojničkih napada na objekte koji drže, odnosno raspolažu većim količinama novca i samozaštita u njima, $13 \mathrm{Maj}$, br.2/85. Beograd

[7] Modly, D.: Osiguranje mjesta događaja, Zagreb, 1993.

[8] Modly, D. (1979) Kriminalistička tehnika u funkciji službe unutrašnjih poslova, Priručnik br. 3., Zagreb.

[9] Modly, D. (1982) Kriminalističko osiguranje tragova i preemeta koji mogu poslužiti kao dokaz u krivičnom postupku,Priručnik br. 1-2., Zagreb.

[10] Modly, D. (1984) Zapisnik o uviđaju, Priručnik br.2., Zagreb.

[11] Modly, D. (1984) Svrha uviđaja i primjena načela hitnosti, priručnik br.5., Zagreb.

[12] Modly, D. (1985) Metodologija provođenja uviđaja (organizacijsko taktički principi istraživanja mjesta događaja), Priručnik br. 3-4., Zagreb.

[13] Modly, D. (1986) Nauka i stručnost u službi pravde, Priručnik br., 6. Zagreb.

[14] Modly, D. (1989) Kriminalistički aspekti pretprocesne djelatnosti organa unutrašnjih poslova, Naša zakonitost, br. 3., Zagreb.

[15] Modly, D. (1990) Najčešće greške uviđajnog organa u toku obavljanja uviđaja i propusti kod sastavljanja zapisnika o uviđaju, Naša zakonitost, 4-5., Zagreb.

[16] Modly, D. (Modly, D. (1999) Kriminalistička policija i istraživanje činjenične situacije, Policija i sigurnost, 5-6., Zagreb.

[17] Modly, D. (2001) Osiguranje mjesta kaznenog događaja, 2. izmijenjeno i dopunjeno izdanje, PUP RH.

[18] Modly,D., Duraković,A. (2016) Metodika istraživanja razbojništava, Centar za 
[19] društvena istraživanja Internacionalnog Burč univerziteta, Sarajevo

[20] Ratcliffe, J. (2004) Strategic Thniking of Criminal Intelligence, The Federation

Press, Sidney.

[21] Richard, J.W.., Ward, H. (2000) Criminal Investigation : A Method for Reconstructing the Past, Andersonn Publishing, Cincinnati.

[22] Ristić, S.: Tehnika i taktika rasvjetljavanja krivičnih djela razbojništava, 13. Maj, br. 11/73. Beograd.

[23] Ristić,S.: Lažna i fingirana razbojništva: 13. Maj, br.9/72.

[24] Roso, Z. (1988) Informativni razgovor i intervju, MUP RH, Zagreb.

[25] Singer, M.: Razbojništva i razbojničke krađe, Priručnik br.1/81. Zagreb. 